\title{
Cellular immunotherapy for malignant gliomas
}

\author{
Yi Lin, MD and \\ Visiting Scholar in Neurological Surgery at University of California San Francisco, Helen Diller \\ Family Cancer Research Building, 1450 3rd Street, San Francisco, CA 94158 \\ Hideho Okada, MD, PhD. \\ Kathleen M. Plant Distinguished Professor in Neurological Surgery at University of California San \\ Francisco, Helen Diller Family Cancer Research Building, 1450 3rd Street, San Francisco, CA \\ 94158; Phone: (415)476-1637; UCSF campus mail box number 0520 \\ Hideho Okada: hideho.okada@ucsf.edu
}

\begin{abstract}
Introduction-Cancer immunotherapy has made much progress in recent years. Clinical trials evaluating a variety of immunotherapeutic approaches are underway in patients with malignant gliomas. Thanks to recent advancements in cell engineering technologies, infusion of ex vivo prepared immune cells have emerged as promising strategies of cancer immunotherapy.
\end{abstract}

Areas covered-Herein, the authors review recent and current studies using cellular immunotherapies for malignant gliomas. Specifically, they cover the following areas: a) cellular vaccine approaches using tumor cell-based or dendritic cell (DC)-based vaccines, and b) adoptive cell transfer (ACT) approaches, including lymphokine-activated killer (LAK) cells, $\gamma \delta \mathrm{T}$ cells, tumor-infiltrating lymphocytes (TIL), chimeric antigen receptor (CAR)-T cells and T-cell receptor (TCR) transduced T cells.

Expert opinion-While some of the recent studies have shown promising results, the ultimate success of cellular immunotherapy in brain tumor patients would require improvements in the following areas: 1) feasibility in producing cellular therapeutics; 2) identification and characterization of targetable antigens given the paucity and heterogeneity of tumor specific antigens; 3) the development of strategies to promote effector T-cell trafficking; 4) overcoming local and systemic immune suppression, and 5) proper interpretation of imaging data for brain tumor patients receiving immunotherapy.

\section{Keywords}

glioma; cellular immunotherapy; dendritic cell vaccine; adoptive cell transfer; CAR-T cell therapy

\footnotetext{
Correspondence to: Hideho Okada, hideho. okada@ucsf . edu.

Declaration of Interest

H Okada is an inventor in the U.S. Patent Application No. 60,611, 797 (Utility Patent Application) "Identification of an IL-13 Receptor Alpha2 Peptide Analogue Capable of Enhancing Stimulation of Glioma-Specific CTL Response". An exclusive licensing agreement has been completed on this application between University of Pittsburgh and Stemline, Inc. In this manuscript, the authors discussed a publication using this peptide, but the data interpretation was done by the entire study team and not by Dr Okada himself. Due to the potential conflicts of interest, Hideho Okada did not solely interpret any data in the current manuscript. The authors have no other relevant affiliations or financial involvement with any organization or entity with a financial interest in or financial conflict with the subject matter or materials discussed in the manuscript apart from those disclosed.
} 


\section{Introduction}

Malignant gliomas are the most common type of primary malignant brain tumor, with more than 18,000 new cases diagnosed each year in the United States ${ }^{1}$. Despite advancements of conventional therapies, including surgery, radiation therapy and chemotherapy, outcomes for these patients remain dismal. Glioblastoma (GBM) is the most common and the most malignant of the gliomas; patients with GBM have a median survival of approximately 15 months following treatment with a combination of chemotherapy (Temozolomide) with radiation therapy ${ }^{2}$, pointing to the urgent need to develop novel efficacious therapeutic modalities.

Cancer immunotherapy is aimed at enhancing the systemic and selective immune response against tumor cells. Both innate and adaptive immune responses play complementary roles. In innate immunity, natural killer (NK) and myeloid cells recognize and destroy virally infected cells and a range of tumor cells in a major histocompatibility complex (MHC)unrestricted manner. Adaptive immune responses are antigen-specific and initiated by presentation of tumor antigens by antigen presenting cells (APCs). Most potent APC are dendritic cells (DCs) which can develop from myeloid cells. DCs present tumor-derived epitope peptides as MHC-peptide complexes to T cells via TCR. Activated T cells clonally expand and then traffic to the tumor-involved organs. T cells recognize antigen epitopes via MHC/peptide complex on tumor cells through the TCR, leading to $\mathrm{T}$ cell activation and release of preformed cytotoxic molecules (granzyme and perforin).

The field of cancer immunotherapy has made exciting breakthroughs in recent years. The United States Food and Drug Administration (FDA) approved monoclonal antibodies (mAb) to the inhibitory immune checkpoint molecules cytotoxic T lymphocyte-4 (CTLA-4; ipilimumab) and programmed death 1 (PD-1; pembroluzimab and nivolumab) for metastatic melanoma as well as non-small cell lung cancer (NSCLC) $)^{3-6}$. In regard to cellular immunotherapy, the FDA approved the first vaccine against non-viral cancers (sipuleucel$\mathrm{T})^{7}$. Furthermore, chimeric antigen receptor (CAR) engineered autologous $\mathrm{T}$ cells have induced durable remissions among leukemia patients refractory to conventional therapies including bone marrow transplantation ${ }^{8,9}$. Extensive preclinical and clinical studies are being conducted to extend these successes to other types of cancer, especially, solid cancer.

Cellular immunotherapeutics could be fundamentally classified into vaccine approaches and adoptive transfer of effector cell approaches. In this review, we discuss recent and current efforts in the field of cellular immunotherapy for malignant gliomas.

\section{Cellular vaccine approaches}

\subsection{Tumor cell vaccines}

Tumor cell vaccines utilize either autologous or allogeneic tumor cells that are attenuated. Since the inherent immunogenicity of the tumor cells may be limited, they are often genetically engineered to express costimulatory molecules, cytokines chemokines, or those in combination ${ }^{10}$. Especially, to enhance the presentation of tumor antigens, cytokines that 
activate antigen-presenting cells (APCs), such as GM-CSF and IL-4 ${ }^{11-13}$, co-stimulatory molecules, such as $\mathrm{CD} 80^{14}$ have been used.

In preclinical studies, peripheral immunization of rats bearing 9L gliosacroma in the brain with IL-4 transfected 9L cells achieved the most potent therapeutic benefit compared to GMCSF, IL-12 and IFN-a ${ }^{15}, 16$. IL-4 produced at the local vaccine site appears to promote a Thelper 1-type antitumor immune response ${ }^{17}$, and the observed therapeutic response was further enhanced in cooperation with local delivery of IFN- $a$ in the intracranial tumor site ${ }^{18}$. A phase I clinical study evaluated safety and immunological activity of a vaccine with autologous tumor cells admixed autologous fibroblasts that are engineered to express IL-4 in patients with recurrent malignant glioma ${ }^{19}$. While only 2 of 6 enrolled participants received scheduled two vaccinations, both participants demonstrated encouraging immunological and clinical and radiological responses ${ }^{19}$. No significant side effects were observed. However, generating sufficient numbers of IL-4-transfected vaccine cells required 7 to 8 weeks. Most participants were withdrawn from the trial because of tumor progression prior to the first vaccination, which posed a major feasibility issue. A phase I/IIa study evaluating autologous formalin-fixed tumor vaccine in newly diagnosed GBM demonstrated feasibility, tolerability as well as encouraging median overall survival (OS) of 22.2 months and a median progression-free survival (PFS) of 8.2 months $^{20}$. More recently, a phase I study was conducted demonstrating the safety and feasibility of vaccination with irradiated autologous glioma cells mixed with irradiated GM-CSF-transduced allogeneic K562 cells in patients with recurrent malignant glioma ${ }^{21}$.

\subsection{Dendritic cell vaccines}

Dendritic cells (DCs) are the most potent APCs, and establishment of methods to culture DCs from peripheral blood-derived monocytes facilitated developments of DC-based vaccines in a variety of cancer types ${ }^{22}$. DCs can be coupled with a variety of tumor antigen sources, such as, synthetic peptides, autologous glioma lysate or acid-eluted glioma peptides. DCs can be directly fused with tumor cells or transfected with tumor RNA, cDNA, or viral vectors ${ }^{23}$.

With the use of whole autologous tumor as the antigen source, DCs can present a wide array of possible tumor antigens to the host immune system ${ }^{24}$. Because DCs present tumorantigens on their MHC molecules, it seems to make the most logical sense if DCs are loaded with acid-eluted peptides derived from autologous tumor cell surface MHC class I molecules. Vaccinations using DCs loaded with autologous acid-eluted peptides were safe ${ }^{25}$, and elicited detectable systemic toxicity and intracranial T-cell infiltration ${ }^{26}$. This method, however, requires $10^{8}-10^{9}$ tumor cells to derive peptides for loading sufficient numbers of DCs, posing a major feasibility challenge.

Use of autologous, whole glioma cell lysate can alleviate this concern as peptides from proteins in the lysate can still be presented by MHC. Wheeler et al. reported the immune and clinical responses from a phase II trial treating 44 patients (34 GBM) with autologous DC pulsed with tumor lysate. Fifty-three percent of GBM patients exhibited $\geq 1.5$ fold vaccineenhanced cytokine responses. Vaccine responders exhibited significantly longer survival relative to nonresponders, with $41 \%$ of vaccine responders survived at least 2 years

Expert Opin Biol Ther. Author manuscript; available in PMC 2017 October 01. 
compared with $7 \%$ of vaccine nonresponders ${ }^{27}$. In another trial, IL-4-transfected fibroblasts admixed with DCs loaded with tumor lysate were given intradermally in five newly diagnosed GBM patients ${ }^{19}$. The median time to progression (TTP) after surgical resection was 6 months. A more recent phase I/II study evaluating a tumor lysate-loaded DC-based vaccine in 77 patients with newly diagnosed GBM showed the feasibility of integrating this treatment in the standard-of-care treatment with surgery, radiotherapy, and chemotherapy. Median OS was 18.3 months since leukapheresis ${ }^{28}$. DCVax is an autologous DC vaccine pulsed with tumor lysate antigen for the treatment of GBM. Autologous tumor lysate-pulsed DC vaccination in conjunction with TLR agonists was evaluated for safety in newly diagnosed and recurrent glioblastoma patients ${ }^{29}$. In addition to encouraging survival data, patients whose tumors had mesenchymal gene expression signatures exhibited increased survival compared with historic controls of the same genetic subtype. Tumor samples with a mesenchymal gene expression signature had a higher number of CD3+ and CD8+ TILs compared with GBMs of other gene expression signatures, suggesting that GBM with the mesenchymal gene expression profile may be more responsive to immune-based therapies. None of these whole-GBM antigen-loaded DC vaccines demonstrated autoimmune encephalitis.

Use of synthetic peptides encoding tumor antigen epitopes provides "off-the-shelf" feasibility thanks to unlimited availability of synthetic peptides. Furthermore, compared with the whole tumor cell antigen-based approaches, use of synthetic peptides targeting tumorspecific (mostly tumor-specific mutation-derived) or tumor-associated (non-mutated but expressed at higher levels in tumor cells vs. normal cells) antigens may reduce the risk of autoimmunity, although selection of antigens is crucial. There are recent excellent reviews on antigens targeted in immunotherapy of gliomas ${ }^{30-33}$.

Several phase I/II trials employing synthetic peptide antigens have been conducted. We have evaluated novel a-type 1 polarizing DCs ( $\mathrm{aDC} 1)$, which were manufactured by maturation of monocyte-derived immature DCs with IL-1 $\beta$, tumor necrosis factor-a, interferon (IFN)$a$, IFN- $\gamma$ and poly-I:C. $a$ DC1 were loaded with synthetic peptides for glioma-associated antigen (GAAs) epitopes and administered in combination with polyinosinic-polycytidylic acid [poly(I:C)] stabilized by lysine and carboxymethylcellulose (poly-ICLC) in HLA-A2(+) patients with recurrent malignant gliomas ${ }^{34}$. GAAs for these peptides are EphA2, interleukin (IL)-13 receptor-alpha2, YKL-40, and gp100. In 22 recurrent high-grade glioma patients who received at least one vaccine, nine patients remained free from progression for at least 12 months. One patient with a GBM had a complete response, and IL-12 production levels by aDC1 positively correlated with time to progression ${ }^{34}$. In another trial, 19 GBM and one brainstem glioma patient received DCs pulsed with tumor-associated antigens (TAA: HER2, TRP-2, gp100, MAGE-1, IL-13Ra2 and AIM-2) ${ }^{35}$. The median OS was 38.4 months for patients with newly diagnosed GBM. OS was positively correlated with quantitative expression of MAGE-1, AIM-2, gp100 and HER2 in patient tumor samples.

Some of recent DC vaccine studies evaluated combination with immunoadjuvants. These include adjuvant cytokine administration (GM-CSF) ${ }^{36}$, and toll-like receptor (TLR) agonists ${ }^{29,34}$. Chemotherapy or antiangiogenic therapy may also potentiate of DC-based immunotherapy ${ }^{37,38}$. However, a very carefully designed study has demonstrated that 
clinically relevant dosages of standard alkylating chemotherapies, such as temozolomide and cyclophosphamide, profoundly inhibit B and T cell responses to vaccines ${ }^{39}$, calling for our cautions designing vaccine studies with concurrent chemotherapy.

Viral antigens may represent particularly attractive targets for immunotherapy because they are foreign to the host immune system and thus are inherently immunogenic. Malignant brain tumors have not been shown to be virally induced, but studies have demonstrated frequent detection of low-level expression of human cytomegalovirus (CMV) genes within malignant gliomas ${ }^{40,41}$. While the role of CMV in the biology of these tumors is a continued area of study ${ }^{40}$, a recent study of a DC vaccine targeting CMV epitopes in GBM demonstrated promising results, especially in combination with the vaccine-site conditioning with tetanus-toxioid ${ }^{42}$.

A number of clinical trials are conducted in malignant gliomas (Table 1). DC-based vaccines for brain tumors appear to be safe and can induce anti-tumor immune response. However, objective clinical benefits (objective anti-tumor response and/or extension of survival) remains to be determined.

\section{Adoptive cell therapy (ACT) of effector cells}

In ACT of effector cells, large numbers (typically $1 \times 10^{6-9}$ orders) of immune effector cells are prepared ex vivo and infused to patients. In brain tumor patients, these cells have been administered locally in the brain tumor site or systemically via i.v. In the past, ex vivo prepared cells with undefined, broad antigen-specificity were mainly used, such as lymphokine-activated killer (LAK) cells. Recently, antigen-targeted approaches have been developed, such as the use of CAR and TCR-transduced cells (Table 2). Even though some of these approaches are quite successful in other cancer types, it is important to address unique challenges that arise when these approaches are applied for brain tumors.

\subsection{LAK cells and NK cells}

LAK cells are autologous peripheral blood lymphocytes stimulated with IL-2 in vitro ${ }^{43}$. Natural killer (NK) cells are the major effector population in LAK cells. They recognize cancer cells in a non-MHC-restricted fashion. LAK cells may represent a primitive immune surveillance system capable of recognizing and destroying altered cells.

A number of clinical studies have been conducted treating GBM or high-grade glioma patients with local injection of LAK cells ${ }^{44}$. These studies demonstrated the safety of infusing autologous leukocytes into the tumor resection cavity. Some of them also have shown promising results in prolonging disease free survival. However, comparison of LAK cell therapy and IL-2 with IL-2 alone showed no significant difference in response rates in patients with renal cell carcinoma ${ }^{45}$. Also high-dose IL-2 may lead to capillary leak syndrome, including hypotension, oliguria, pulmonary edema and dyspnea, discouraging further study of the approach. Thus, a randomized phase II or III clinical study was never conducted. However, owing to recent advances in the field of $\mathrm{NK}$ cell biology ${ }^{46}$, there is a renewed interest in NK cell-based immunotherapy for cancer ${ }^{47}$. Recent preclinical advancements of NK cell immunotherapy include augmentation of antibody-dependent 
cellular cytotoxicity, manipulation of receptor-mediated activation, and adoptive immunotherapy with ex vivo-expanded, CAR-engineered NK cells (reviewed in ${ }^{48}$ ).

\section{$3.2 \gamma \delta \mathrm{T}$ cells}

In healthy donors, $\mathrm{T}$ cells bearing the $\gamma \delta \mathrm{T}$ cell receptor constitute $0.5-20 \%$ of CD3+ T lymphocytes in peripheral blood and in lymphoid tissues ${ }^{49}$. They can be isolated then expanded by IFN- $\gamma$, IL-2, monoclonal antibody against CD3, and IL- $1 a^{50} \cdot \gamma \delta$ T cells express natural cytotoxicity receptor natural killer $\mathrm{p} 44$, and exert their cytolytic activity mainly via the non-MHC-restricted $\gamma \delta \mathrm{TCR}^{51}$. Activating NK cell receptors such as NKG2D and DNAM1 are also present on most $\gamma \delta$ T cells, which recognize stress-induced ligands on tumor cells ${ }^{50}, 52$. Early phase clinical trials have been conducted in non-Hodgkin lymphoma, multiple myeloma, and metastatic solid tumors ${ }^{53}$. In brain tumors, preclinical studies also suggested that $\gamma \delta$ T-cell depletion and impaired function occur prior to or concurrent with the growth of the brain tumor ${ }^{54}$. Expanded/activated $\gamma \delta$ T-cells from both healthy controls and selected patients have significant cytotoxicity against primary GBM explants ${ }^{55}$. Also there are evidence that $\gamma \delta \mathrm{T}$ cell therapy may be safe for brain tumor patients who undergo standard cytotoxic therapies ${ }^{56,57}$, opening a previously unexplored approach to cellular immunotherapy of brain tumors.

\subsection{TIL transfer}

TILs are obtained from tumor tissue, draining lymph nodes or malignant effusions. They contain high numbers of tumor-specific $\mathrm{T}$ cells that presumably have already been selected for their ability to recognize and respond to the tumor antigens. While TILs may not possess sufficient antitumor activity in the highly immunosuppressive microenvironment established by tumors, activation and expansion of TILs ex vivo can overcome these immunosuppressive effects and allow for the generation of sufficient numbers of TILs for adoptive immunotherapy. These TILs are expanded ex vivo with high dose IL-2, then transferred back to the patient.

Adoptive cell therapy with TILs in combination with lymphodepletion and high-dose IL-2 has mediated durable, complete regressions in patients with melanoma, with reproducible objective response rates of approximately $50 \%$ in patients with highly advanced, refractory metastatic melanoma, probably by targeting somatic mutations exclusive to each cancer ${ }^{58}$. However, in brain tumors only few attempts have been made ${ }^{59-61}$. This may be because obtaining and expanding enough numbers of TILs require highly immunogenic, large, and accessible tumors. For malignancies other than melanoma, it has been very difficult to expand TILs from tumor tissues ${ }^{62}$. Also T cells present at the tumor bed are often exhausted, limiting their functions and their proliferative capacity. To overcome this issue for gliomas, a clinical trial was performed first vaccinating patients with irradiated autologous tumor cells, then harvesting tumor-draining lymph node T cells, expanding them ex vivo with anti-CD3 antibody and bacterial superantigen Staphylococcal enterotoxin A, and systemically infusing these cells ${ }^{63,64}$. Three out of ten patients with recurrent malignant gliomas ${ }^{63}$ and four out of ten patients with newly diagnosed malignant gliomas ${ }^{64}$ showed radiographic partial response. However, no study has proven prolongation of the survival of glioma patients.

Expert Opin Biol Ther. Author manuscript; available in PMC 2017 October 01. 


\subsection{Adoptive transfer of genetically engineered T-cells (CAR and TCR)}

3.4.1 a $\beta$ T-Cell Receptors-The cDNAs for the $a$ - and $\beta$-chains of the TCR are cloned from class I HLA-restricted TCRs of tumor-reactive cytotoxic T cells and transferred to fresh T cells. Several TCRs have been cloned for several HLA-restricted epitopes encoded by TAAs ${ }^{65-68}$. Genetic modification of $\mathrm{T}$ cells with $\alpha / \beta$ TCRs also requires high expression and correct pairing of two different receptor molecules from a single vector, which has proved problematic for transgenic $\alpha / \beta$ TCRs, especially because mispairing between transgene- or endogenous TCR-derived $\alpha$ and $\beta$ chain can occur. A variety of geneengineering technologies have been evaluated, such as small interfering RNA constructs that specifically down-regulate endogenous TCR ${ }^{69}$ a disulfide bridge in the $\alpha / \beta$ constant $(C)$ regions by the extra cysteine residues; substituting human with murine $\mathrm{C}$ regions; codon optimization to enhance protein synthesis; TCR chain leucine zipper fusions; and a single chain TCR (reviewed ${ }^{70,71}$ ).

In the first reported trial to examine the in vivo efficacy of TCR-transduced T cells in patients with cancer, the adoptive transfer of autologous T cells that were transduced with a MART-1-reactive TCR lead to tumor regression in 2 of 15 treated patients with metastatic melanoma ${ }^{65}$. Another study using autologous T-cells transduced with TCR treated 36 patients with metastatic melanoma using high-avidity TCRs that recognized either the MART-1 or gp100 melanoma-melanocyte antigens ${ }^{67}$. Objective cancer regressions were observed in $30 \%$ and $19 \%$ of patients who received the MART-1 or gp100 TCR, respectively, but severe off-tumor, on-target toxicity was seen in the skin, eyes, and ears due to the presence of melanocytes in these organs. The use of a high-affinity TCR against the carcinoembryonic antigen (CEA) in patients with metastatic colorectal cancer that expressed high levels of this antigen ${ }^{72}$ was halted when all 3 patients experienced life-threatening colitis and colonic hemorrhage. Unexpected toxicities can also present when previously unknown cross-reactive targets are expressed in healthy vital organs. For example, while MAGE-A3 is not known to be expressed in any normal tissues, targeting an HLA-A2.1restricted peptide in MAGE-A3 caused severe damage to brain gray matter, resulting in 2 deaths because this TCR homed to a different but related epitope expressed by MAGE-A12 at very low levels in the brain ${ }^{73}$.

A TCR directed against NY-ESO-1, a cancer germline antigen expressed in a variety of solid cancers holds promise. Objective responses were observed in 11 of the 18 patients (61\%) with synovial cell sarcoma and 11 of the 20 patients (55\%) with melanoma who received autologous TCR-transduced cells. The total number of T cells and the number of antigenreactive $\mathrm{T}$ cells administered to patients correlated with response to therapy. However, there was a lack of a correlation between clinical responsiveness and persistence of infused $\mathrm{T}$ cells, possibly resulted from a failure of the T cells to persist for longer time periods ${ }^{75}$. NYESO-1-specific TCR-engineered T cells also showed encouraging clinical response in 16 of 20 patients with myeloma, in which engineered T cells expanded, persisted, trafficked to bone marrow and exhibited a cytotoxic phenotype. Disease progression was associated with loss of $\mathrm{T}$ cell persistence or antigen escape ${ }^{76}$. For brain tumors, however, no clinical study with a $\beta$ TCR T cells has been initiated.

Expert Opin Biol Ther. Author manuscript; available in PMC 2017 October 01. 
3.4.2 CAR-T cells-CAR engineering involves transgene-expression of single chain variable fragment ( $\mathrm{scFv}$ ) of a monoclonal antibody $(\mathrm{Ab})$, which is specific for a tumor cell surface protein, at the surface of $\mathrm{T}$ cells, allowing the $\mathrm{T}$ cells to recognize tumor directly and not through the MHC complex. The Ab is linked to the $\mathrm{CD} 3 \zeta$ chain and other $\mathrm{T}$ cell activation pathways, allowing T cell activation and target cell killing ${ }^{77,78}$. In addition, Abs bind antigens with much greater affinity than do TCRs, resulting in the formation of a more stable immunological synapse ${ }^{79}$. CARs have evolved over the last decade, with progressively increasing co-stimulatory activity. In addition to a single signaling unit derived from the $\mathrm{CD} 3 \zeta$ chain or the high-affinity $\mathrm{IgG}$ receptor $\mathrm{Fc} 1 \mathrm{RIg}^{80}$, second-generation CARs incorporate the intracellular domain of a co-stimulatory molecule, CD28. Subsequent incorporation of both $\mathrm{CD} 28$ and a tumor necrosis factor receptor family member CD137 (4-1BB), CD 27, CD134 (OX40), CD244, or ICOS has enhanced the ability of these receptors to stimulate cytokine secretion and $\mathrm{T}$ cell proliferation and persistence in preclinical studies ${ }^{81}$. Compared with TCR engineered T cells, CAR engineered T cells are applicable to all patients irrespective of their HLA alleles expressed, and circumvent tumor evasion through HLA down-regulation.

CARs have been generated for the glioma cell surface antigens, including IL-13Ra $2^{82}$, HER $2^{83}$, EphA2 ${ }^{84}$, and EGFRvIII ${ }^{85-87}$. It should also be noted that CARs can induce toxicity against self-antigens as well. Acute pulmonary toxicity resulting in death was observed after infusion of CAR-T cells specific for ERBB2, likely due to the recognition of low levels of this antigen on pulmonary epithelium ${ }^{74}$. These observations underscore the need for selecting tumor-specific antigens, such as tumor-specific mutation-derived antigens (i.e., neoantigens), for effective and safe ACT. Among these targets, only EGFRvIII is tumor-specific, while others are TAAs. In preclinical animal models, $\mathrm{T}$ cells expressing these EGFRvIII-specific CARs showed potent antitumor activity ${ }^{85}$, 86. Phase I clinical trials of CART cells that are engineered to target HER2 (NCT02442297) or EGFRvIII mutation (NCT01454596 and NCT02209376) in patients with GBM are ongoing. A phase I clinical study with $\mathrm{T}$ cells expressing IL13Ra2-specific CAR has demonstrated safety in patients with recurrent $\mathrm{GBM}^{88}$.

Most individuals naturally have high-avidity T-cells against viral epitopes at high frequencies. Transduction of viral antigen-specific T-cells with CAR may allow restimulation of CAR-transduced T-cells via the endogenous viral antigen-specific TCR (e.g. CMV-specific TCR) and the corresponding epitope (bispecific T cells). A phase I clinical studies with CMV-specific "bispecific" T-cells transduced with anti-HER2 CAR has been initiated (NCT01109095). A study with T cells expressing HER2-specific CARs showed that these cells had potent antitumor activity against HER2-positive, CD133-positive glioma stem cells ${ }^{83}$. A similar bispecific T cell, anti-GD2 CAR EBV-specific T cells, is being conducted as a phase I study in patients with refractory/relapsed neuroblastoma (NCT00085930). EBV-specific T cells, expressing a GD2- $\zeta$ CAR, persisted significantly longer than control, non-viral specific GD2- $\zeta$ T cells. Infusion of GD2-specific T cells resulted in tumor necrosis or regression (including a complete remission) in four out of eight patients ${ }^{89}$. 
A number of ways have been explored to increase the specificity of CAR-T cells to achieve a more promising, safer targeting. CAR-T cells can be genetically modified to recognize two or more tumor- associated antigens, which can enhance discrimination between abnormal and healthy tissue. One can transfer two CARs ${ }^{90}$; split-signal CARs, which can limit full T cell activation to tumors expressing multiple antigens ${ }^{91,92}$; tandem CARs (TanCARs), which contain ectodomains with two scFvs ${ }^{93}$, also limiting the risk of immune escape; or co-expression of inhibitory CARs (iCARs) directed against molecules in healthy organs together with their activating counterparts (reviewed with a schema in ${ }^{94}$ ). Furthermore, a novel approach has been developed to engineer the T cells with dual-receptor circuits, in which a synthetic Notch receptor for one antigen induces the expression of a CAR for a second antigen ${ }^{95}$.

\section{Conclusion}

We discussed recent developments of cellular immunotherapy for malignant brain tumors. While some of novel cellular therapeutics, such as CAR therapy, have demonstrated remarkable successes in other cancer types, translation of those successes to brain tumors will not be achieved unless we gain in-depth understanding of the unique immunological environment of brain tumors and develop strategies that are adequate to overcome challenges associated with the environment. In the "Expert Opinion" section below, we will further discuss our perspective.

\section{Expert Opinion}

After decades of efforts to revise the longstanding dogma that the brain and tumors arising therein are "immunologically privileged", immunotherapy, including cellular immunotherapy, for brain tumors has been emerging as a promising approach. However, the ultimate success of cellular immunotherapy in brain tumor patients would require advancements in the following areas: 1) feasibility of timely production of cellular therapeutics; 2) paucity and heterogeneity of tumor specific antigens; 3) better strategies to promote antigen-presentation and effector T-cell trafficking; 4) local and systemic immune suppression, and 5) proper interpretation of imaging data for brain tumor patients receiving immunotherapy.

\subsection{Feasibility of Producing Cellular Therapeutics}

Production of autologous cell products inevitably involves lengthy and intensive processes, such as leukapheresis, engineering, expansion, as well as quality-assurance tests and assays. There require substantial costs, infrastructure of the institution as well as invasive procedures for patients, such as leukapheresis. These are important issues to address, especially because we hope that cellular immunotherapy will become effective, standard-of-care therapy in future. Ongoing efforts are directed to development of efficient bioreactors and automated processing systems. Another way to solve the issue is to develop "off-the-shelf" allogeneic cell products that can be safely administered without being rejected by the host immunesystem. While this requires multiple immuno-genetic engineering of cells, developments are underway in this direction.

Expert Opin Biol Ther. Author manuscript; available in PMC 2017 October 01. 


\subsection{Paucity of tumor-specific antigens and heterogeneity of antigen-expression}

Although the list of antigens that could be used for immunotherapy of brain tumors has expanded over the last decade ${ }^{31}$, there are not many truly brain tumor-specific antigens, except for those derived from EGFRvIII and mutant IDH $1^{96}$. Use of tumor-associated, but non-specific antigens (TAAs as referred in this manuscripts) can cause life-threatening and fatal events by on-target ${ }^{72}$ or off-target ${ }^{97}$ cross-reactivity of T-cells against normal cells. Furthermore, due to marked heterogeneity of genetics and protein expression in solid cancers, targeting a single antigen may result in the evolution of variants that lack the target antigen ${ }^{98}$. These observations underscore the need for expanding the list of available tumorspecific antigens, such as mutation-derived antigens (i.e., neoantigens), for effective and safe immunotherapy. Extension of these approaches should foster broader availability of target antigens for immunotherapy of brain tumors.

\subsection{Better Strategies to Promote Antigen-Presentation and Effector T-cell Trafficking}

While brain tumors are heavily infiltrated by myeloid cells, the vast majority of them are suppressive for effector T-cell functions but not effective APCs ${ }^{99}$. Efforts are being undertaken to modulate the function of these cells and promote their function as type-1 APCs. In regard to T-cell homing to brain tumors, although T-cells are able to traverse the blood-brain-barrier via chemokine axes and multistep adhesion processes, homing of effector CTL is weaker in brain tumors compared with cancer in other organs ${ }^{100,101}$. To date, there have not been many immunotherapy regimens for brain tumors incorporating therapeutic agents that can facilitate T-cell homing to the brain tumor site. Our regimens using poly-ICLC have been among the first to address this issue and are expected to enhance T-cell homing to the glioma site ${ }^{34,100,102}$. In other organ sites, Kershaw et al. have demonstrated that engineering the chemokine receptor CXCR2 into $\mathrm{T}$ cells enabled the $\mathrm{T}$ cells to efficiently migrate toward melanoma ${ }^{103}$. Transgenic co-expression of CCR4 improved the homing of CAR-CD30-modified T cells to CD30+ Hodgkin lymphoma that secreted CCL17 (the ligand for CCR4) ${ }^{104}$. Enhanced CCR2b expression from mesothelinreactive CAR-T cells and CAR-GD2 T cells led to improved anti- tumor effects against malignant pleural mesothelioma and neuroblastoma ${ }^{105,106}$. Some of these inventions may be applicable for brain tumors as well.

\subsection{Local and Systemic Immune Suppression}

Brain tumors mediate a variety of immunosuppressive mechanisms to escape from immunological attacks. These include expression of check-point molecules and immunosuppressive cytokines as well as recruitment of regulatory T-cells and immunosuppressive myeloid cells. Furthermore, it is important to recognize that significant levels of systemic immunosuppression are likely caused by treatments for these patients. These include chemotherapy, such as temozolomide ${ }^{39}$ as standard-of-care, corticosteroids as well as radiation therapy. Grossman et al have suggested that lymphocyte counts alone are predictive of prognosis, with lower counts correlating with shorter survival in patients with $\mathrm{GBM}^{107}$. It is important to address how we can minimize the impact of treatment-induced immunosuppression by the time the patient receives immunotherapy, although for adoptive 
transfer of T-cells, lymphopenic conditions induced by prior treatments may serve as a proper "conditioning", thereby promoting post-infusion expansion of T-cells.

In CAR T cells, post-infusion in vivo activity is mainly supported through addition of costimulatory molecules in the CAR construct. Recently, TRUCK T cells, also called fourthgeneration CARs, were developed involving two separate transgenes, with the CAR gene and a $\mathrm{T}$ cell activation responsive promoter linked to a cytokine ${ }^{108}$. Studies have shown that therapy with $\mathrm{T}$ cells engineered to express IL-12 could change the tumor microenvironment and enhance anti-tumor function ${ }^{109,110}$. IL-12 secretion by engineered T cells expressing CARs resulted in the destruction of antigen negative cancer cells that may escape from $\mathrm{T}$ cell therapy ${ }^{111}$. Also antigen-specific $\mathrm{T}$ cells expressing dnTGF- $\beta$ RII were resistant to the anti-proliferative effects of TGF- $\beta$ and retained their effector function in vivo ${ }^{112}$. On the other hand, CAR-T cells also express PD1, and are susceptible to PD1/PDL1 interactionmediated suppression ${ }^{113}$. It has been shown that blocking PD1 immunosuppression can boost CAR-T cell therapy, likely representing a fruitful area for future study ${ }^{114,115}$.

\subsection{Proper interpretation of imaging data for brain tumor patients receiving immunotherapy}

Early phase immunotherapy clinical trials in brain tumor patients have revealed unique challenges associated with assessment of radiological changes reflecting delayed responses or therapy-induced inflammation ${ }^{116}$. Neuroimaging often reveals temporary worsening of abnormal findings and even appearance of new lesions. Clinical benefit, including long-term survival and tumor regression, can still occur following initial apparent progression. A multinational and multidisciplinary panel of neuro-oncology immunotherapy experts recently described immunotherapy response assessment for neuro-oncology (iRANO) criteria ${ }^{117}$ that are based on guidance for determination of tumor progression outlined by the immune-related response criteria (irRC) ${ }^{118}$ and the response assessment in neurooncology (RANO) working group ${ }^{119}$. The iRANO guidelines specifically address interpretation of initial progressive imaging findings in the context of neuro-oncology patients with a goal of decreasing the likelihood of premature discontinuation of potentially beneficial therapies while ensuring maximum patient safety. Prospective evaluation of the iRANO criteria in brain tumor immunotherapy trials for neuro-oncology patients will be required to improve their ultimate clinical utility.

To address above discussed issues, it is apparent that our ultimate success will largely hinge upon effective collaboration across multiple disciplines. Scientifically, we have to integrate cutting edge progresses in both cancer immunology and central nervous system immunology. To implement novel combination strategies, it is essential to promote effective collaboration across companies and regulatory authorities. Encouraged by recent success in cancer immunotherapy for other cancer types, we believe that we are on the right direction and hope that we will develop truly effective immunotherapies for patients with malignant brain tumors.

\section{Acknowledgments}

Funding:

Expert Opin Biol Ther. Author manuscript; available in PMC 2017 October 01. 
This work is supported by NIH grant R21NS083171 through H Okada.

\section{References}

1. Ostrom QT, Gittleman H, Fulop J, et al. CBTRUS Statistical Report: Primary Brain and Central Nervous System Tumors Diagnosed in the United States in 2008-2012. Neuro Oncol. 2015 Oct; 17(Suppl 4):iv1-iv62. [PubMed: 26511214]

2. Stupp R, Mason WP, van den Bent MJ, et al. Radiotherapy plus concomitant and adjuvant temozolomide for glioblastoma. NEnglJMed. 2005; 352(10):987-96.

3. Hodi FS, O'Day SJ, McDermott DF, et al. Improved survival with ipilimumab in patients with metastatic melanoma. The New England journal of medicine. 2010 Aug 19; 363(8):711-23. [PubMed: 20525992]

4. Robert C, Long GV, Brady B, et al. Nivolumab in previously untreated melanoma without BRAF mutation. N Engl J Med. 2015 Jan 22; 372(4):320-30. [PubMed: 25399552]

5. Robert C, Ribas A, Wolchok JD, et al. Anti-programmed-death-receptor-1 treatment with pembrolizumab in ipilimumab-refractory advanced melanoma: a randomised dose-comparison cohort of a phase 1 trial. Lancet. 2014 Sep 20; 384(9948):1109-17. [PubMed: 25034862]

6. Sundar R, Cho BC, Brahmer JR, et al. Nivolumab in NSCLC: latest evidence and clinical potential. Ther Adv Med Oncol. 2015 Mar; 7(2):85-96. [PubMed: 25755681]

7. Kantoff PW, Higano CS, Shore ND, et al. Sipuleucel-T immunotherapy for castration-resistant prostate cancer. The New England journal of medicine. $2010 \mathrm{Jul} 29$; 363(5):411-22. [PubMed: 20818862]

8. Maude SL, Frey N, Shaw PA, et al. Chimeric antigen receptor T cells for sustained remissions in leukemia. N Engl J Med. 2014 Oct 16; 371(16):1507-17. [PubMed: 25317870]

9. Grupp SA, Kalos M, Barrett D, et al. Chimeric antigen receptor-modified T cells for acute lymphoid leukemia. N Engl J Med. 2013 Apr 18; 368(16):1509-18. [PubMed: 23527958]

10. Dilloo D, Bacon K, Holden W, et al. Combined chemokine and cytokine gene transfer enhances antitumor immunity. Nat Med. 1996 Oct; 2(10):1090-5. [PubMed: 8837606]

11. Okada H, Lieberman FS, Walter KA, et al. Autologous glioma cell vaccine admixed with interleukin-4 gene transfected fibroblasts in the treatment of patients with malignant gliomas. Journal of translational medicine. 2007; 5:67. [PubMed: 18093335]

12. Kusumoto M, Umeda S, Ikubo A, et al. Phase 1 clinical trial of irradiated autologous melanoma cells adenovirally transduced with human GM-CSF gene. Cancer Immunol Immunother. 2001 Sep; 50(7):373-81. [PubMed: 11676397]

13. Dranoff G, Jaffee E, Lazenby A, et al. Vaccination with irradiated tumor cells engineered to secrete murine granulocyte-macrophage colony-stimulating factor stimulates potent, specific, and longlasting anti-tumor immunity. Proc Natl Acad Sci U S A. 1993 Apr 15; 90(8):3539-43. [PubMed: 8097319]

14. Dols A, Smith JW 2nd, Meijer SL, et al. Vaccination of women with metastatic breast cancer, using a costimulatory gene (CD80)-modified, HLA-A2-matched, allogeneic, breast cancer cell line: clinical and immunological results. Human gene therapy. 2003 Jul 20; 14(11):1117-23. [PubMed: 12885350]

15. Okada H, Giezeman-Smits KM, Tahara H, et al. Effective cytokine gene therapy against an intracranial glioma using a retrovirally transduced IL-4 plus HSVtk tumor vaccine. Gene Ther. 1999 Feb; 6(2):219-26. [PubMed: 10435106]

16. Okada H, Villa L, Attanucci J, et al. Cytokine gene therapy of gliomas: effective induction of therapeutic immunity to intracranial tumors by peripheral immunization with interleukin-4 transduced glioma cells. Gene Ther. 2001 Aug; 8(15):1157-66. [PubMed: 11509946]

17. Eguchi J, Hiroishi K, Ishii S, et al. Interleukin-4 gene transduced tumor cells promote a potent tumor-specific Th1-type response in cooperation with interferon-alpha transduction. Gene Ther. 2005; 12:733-41. [PubMed: 15772692]

18. Kuwashima N, Nishimura F, Eguchi J, et al. Delivery of Dendritic Cells Engineered to Secrete IFN-\{alpha\} into Central Nervous System Tumors Enhances the Efficacy of Peripheral Tumor Cell

Expert Opin Biol Ther. Author manuscript; available in PMC 2017 October 01. 
Vaccines: Dependence on Apoptotic Pathways. J Immunol. 2005; 175(4):2730-40. [PubMed: 16081851]

19. Okada H, Lieberman FS, Walter KA, et al. Autologous glioma cell vaccine admixed with interleukin-4 gene transfected fibroblasts in the treatment of patients with malignant gliomas. J Transl Med. 2007; 5(1):67. [PubMed: 18093335]

20. Ishikawa E, Muragaki Y, Yamamoto T, et al. Phase I/IIa trial of fractionated radiotherapy, temozolomide, and autologous formalin-fixed tumor vaccine for newly diagnosed glioblastoma. $\mathbf{J}$ Neurosurg. 2014 Sep; 121(3):543-53. [PubMed: 24995786]

21. Curry WT Jr, Gorrepati R, Piesche M, et al. Vaccination with Irradiated Autologous Tumor Cells Mixed with Irradiated GM-K562 Cells Stimulates Antitumor Immunity and T Lymphocyte Activation in Patients with Recurrent Malignant Glioma. Clinical cancer research : an official journal of the American Association for Cancer Research. 2016 Feb 12.

22. Kalinski P, Edington H, Zeh HJ, et al. Dendritic cells in cancer immunotherapy: vaccines or autologous transplants? Immunologic research. 2011 Aug; 50(2-3):235-47. [PubMed: 21717071]

23. Ajay D, Sanchez-Perez L, Choi BD, et al. Immunotherapy with tumor vaccines for the treatment of malignant gliomas. Curr Drug Discov Technol. 2012 Dec; 9(4):237-55. [PubMed: 22339070]

24. De Vleeschouwer S, Van Gool SW, Van Calenbergh F. Immunotherapy for malignant gliomas: emphasis on strategies of active specific immunotherapy using autologous dendritic cells. Childs Nerv Syst. 2005 Jan; 21(1):7-18. [PubMed: 15452731]

25. Liau LM, Black KL, Martin NA, et al. Treatment of a patient by vaccination with autologous dendritic cells pulsed with allogeneic major histocompatibility complex class I-matched tumor peptides. Case Report. Neurosurg Focus. 2000; 9(6):e8.

26. Yu JS, Wheeler CJ, Zeltzer PM, et al. Vaccination of malignant glioma patients with peptide-pulsed dendritic cells elicits systemic cytotoxicity and intracranial T-cell infiltration. Cancer research. 2001 Feb 1; 61(3):842-7. [PubMed: 11221866]

27. Wheeler CJ, Black KL, Liu G, et al. Vaccination elicits correlated immune and clinical responses in glioblastoma multiforme patients. Cancer research. 2008 Jul 15; 68(14):5955-64. [PubMed: 18632651]

28. Ardon H, Van Gool SW, Verschuere T, et al. Integration of autologous dendritic cell-based immunotherapy in the standard of care treatment for patients with newly diagnosed glioblastoma: results of the HGG-2006 phase I/II trial. Cancer Immunol Immunother. 2012 Nov; 61(11):203344. [PubMed: 22527250]

29. Prins RM, Soto H, Konkankit V, et al. Gene expression profile correlates with T-cell infiltration and relative survival in glioblastoma patients vaccinated with dendritic cell immunotherapy. Clin Cancer Res. 2011 Mar 15; 17(6):1603-15. [PubMed: 21135147]

30. Okada H. Brain tumor immunotherapy with type-1 polarizing strategies. Ann N Y Acad Sci. 2009 Sep.1174:18-23. [PubMed: 19769732]

31. Sampson JH, Mitchell DA. Vaccination strategies for neuro-oncology. Neuro Oncol. 2015 Nov; 17(Suppl 7):vii15-vii25. [PubMed: 26516221]

32. Reardon DA, Freeman G, Wu C, et al. Immunotherapy advances for glioblastoma. Neurooncology. 2014 Nov; 16(11):1441-58. [PubMed: 25190673]

33*. Reardon DA, Wucherpfennig KW, Freeman G, et al. An update on vaccine therapy and other immunotherapeutic approaches for glioblastoma. Expert Rev Vaccines. 2013 Jun; 12(6):597-615. Excellent review providing an updated and comprehensive information on recent immunotherapy approaches for glioblastomas. [PubMed: 23750791]

34. Okada H, Kalinski P, Ueda R, et al. Induction of CD8+ T-Cell Responses Against Novel GliomaAssociated Antigen Peptides and Clinical Activity by Vaccinations With \{alpha $\}$-Type 1 Polarized Dendritic Cells and Polyinosinic-Polycytidylic Acid Stabilized by Lysine and Carboxymethylcellulose in Patients With Recurrent Malignant Glioma. J Clin Oncol. 2011 Jan 20; 29(3):330-36. [PubMed: 21149657]

35. Phuphanich S, Wheeler CJ, Rudnick JD, et al. Phase I trial of a multi-epitope-pulsed dendritic cell vaccine for patients with newly diagnosed glioblastoma. Cancer Immunol Immunother. 2013 Jan; 62(1):125-35. [PubMed: 22847020] 
36. Slingluff CL Jr, Petroni GR, Yamshchikov GV, et al. Clinical and immunologic results of a randomized phase II trial of vaccination using four melanoma peptides either administered in granulocyte-macrophage colony-stimulating factor in adjuvant or pulsed on dendritic cells. J Clin Oncol. 2003 Nov 1; 21(21):4016-26. [PubMed: 14581425]

37. Wheeler CJ, Das A, Liu G, et al. Clinical responsiveness of glioblastoma multiforme to chemotherapy after vaccination. Clinical cancer research : an official journal of the American Association for Cancer Research. 2004 Aug 15; 10(16):5316-26. [PubMed: 15328167]

38. Bloch O, Crane CA, Fuks Y, et al. Heat-shock protein peptide complex-96 vaccination for recurrent glioblastoma: a phase II, single-arm trial. Neuro Oncol. 2014 Jan; 16(2):274-9. [PubMed: 24335700]

39*. Litterman AJ, Zellmer DM, Grinnen KL, et al. Profound impairment of adaptive immune responses by alkylating chemotherapy. Journal of immunology. 2013 Jun 15; 190(12):6259-68. A very well designed and considerate study evaluating impacts of chemotherapy on vaccinereactive $\mathrm{T}$ cells in preclinical glioma vaccine models.

40. Dziurzynski K, Chang SM, Heimberger AB, et al. Consensus on the role of human cytomegalovirus in glioblastoma. Neuro-Oncology. Mar 1; 2012 14(3):246-55. [PubMed: 22319219]

41. Cobbs CS, Harkins L, Samanta M, et al. Human cytomegalovirus infection and expression in human malignant glioma. Cancer Res. 2002; 62(12):3347-50. [PubMed: 12067971]

42*. Mitchell DA, Batich KA, Gunn MD, et al. Tetanus toxoid and CCL3 improve dendritic cell vaccines in mice and glioblastoma patients. Nature. 2015 Mar 19; 519(7543):366-9. An important clinical study demonstrating the role of vaccine-site conditioning by Tetanus Toxoid. [PubMed: 25762141]

43. Merchant RE, Ellison MD, Young HF. Immunotherapy for malignant glioma using human recombinant interleukin-2 and activated autologous lymphocytes. A review of pre-clinical and clinical investigations. Journal of neuro-oncology. 1990 Apr; 8(2):173-88. [PubMed: 2193121]

44. Ishikawa E, Takano S, Ohno T, et al. Adoptive cell transfer therapy for malignant gliomas. Adv Exp Med Biol. 2012; 746:109-20. [PubMed: 22639163]

45. Law TM, Motzer RJ, Mazumdar M, et al. Phase III randomized trial of interleukin-2 with or without lymphokine-activated killer cells in the treatment of patients with advanced renal cell carcinoma. Cancer. 1995 Sep 1; 76(5):824-32. [PubMed: 8625186]

46. Fujisaki H, Kakuda H, Shimasaki N, et al. Expansion of highly cytotoxic human natural killer cells for cancer cell therapy. Cancer research. 2009 May 1; 69(9):4010-7. [PubMed: 19383914]

47. Barkholt L, Alici E, Conrad R, et al. Safety analysis of ex vivo-expanded NK and NK-like T cells administered to cancer patients: a phase I clinical study. Immunotherapy. 2009 Sep; 1(5):753-64. [PubMed: 20636021]

48. Rezvani K, Rouce RH. The Application of Natural Killer Cell Immunotherapy for the Treatment of Cancer. Front Immunol. 2015; 6:578. [PubMed: 26635792]

49. Groh V, Porcelli S, Fabbi M, et al. Human lymphocytes bearing T cell receptor gamma/delta are phenotypically diverse and evenly distributed throughout the lymphoid system. J Exp Med. 1989 Apr 1; 169(4):1277-94. [PubMed: 2564416]

50. von Lilienfeld-Toal M, Nattermann J, Feldmann G, et al. Activated gammadelta T cells express the natural cytotoxicity receptor natural killer p 44 and show cytotoxic activity against myeloma cells. Clin Exp Immunol. 2006 Jun; 144(3):528-33. [PubMed: 16734623]

51. Girardi M, Oppenheim DE, Steele CR, et al. Regulation of cutaneous malignancy by gammadelta T cells. Science. 2001 Oct 19; 294(5542):605-9. [PubMed: 11567106]

52. Deniger DC, Maiti SN, Mi T, et al. Activating and propagating polyclonal gamma delta T cells with broad specificity for malignancies. Clin Cancer Res. 2014 Nov 15; 20(22):5708-19. [PubMed: 24833662]

53. Nicol AJ, Tokuyama H, Mattarollo SR, et al. Clinical evaluation of autologous gamma delta T cellbased immunotherapy for metastatic solid tumours. British journal of cancer. 2011 Sep 6; 105(6): 778-86. [PubMed: 21847128]

54. Lamb LS Jr. Gammadelta T cells as immune effectors against high-grade gliomas. Immunol Res. 2009; 45(1):85-95. [PubMed: 19711198]

Expert Opin Biol Ther. Author manuscript; available in PMC 2017 October 01. 
55. Bryant NL, Gillespie GY, Lopez RD, et al. Preclinical evaluation of ex vivo expanded/activated gammadelta $\mathrm{T}$ cells for immunotherapy of glioblastoma multiforme. Journal of neuro-oncology. 2011 Jan; 101(2):179-88. [PubMed: 20532954]

56. Pereboeva L, Harkins L, Wong S, et al. The safety of allogeneic innate lymphocyte therapy for glioma patients with prior cranial irradiation. Cancer Immunol Immunother. 2015 May; 64(5): 551-62. [PubMed: 25676710]

57. Lamb LS Jr, Bowersock J, Dasgupta A, et al. Engineered drug resistant gammadelta T cells kill glioblastoma cell lines during a chemotherapy challenge: a strategy for combining chemo- and immunotherapy. PLoS One. 2013; 8(1):e51805. [PubMed: 23326319]

$58 * *$. Rosenberg SA, Restifo NP. Adoptive cell transfer as personalized immunotherapy for human cancer. Science. 2015 Apr 3; 348(6230):62-8. An updated, comprehensive and insightful review on adoptive cell transfer approach for cancer. [PubMed: 25838374]

59. Saris SC, Spiess P, Lieberman DM, et al. Treatment of murine primary brain tumors with systemic interleukin-2 and tumor-infiltrating lymphocytes. J Neurosurg. 1992 Mar; 76(3):513-9. [PubMed: 1738033]

60. Quattrocchi KB, Miller CH, Cush S, et al. Pilot study of local autologous tumor infiltrating lymphocytes for the treatment of recurrent malignant gliomas. Journal of neuro-oncology. 1999; 45(2):141-57. [PubMed: 10778730]

61. Glitza IC, Haymaker C, Bernatchez C, et al. Intrathecal Administration of Tumor-Infiltrating Lymphocytes Is Well Tolerated in a Patient with Leptomeningeal Disease from Metastatic Melanoma: A Case Report. Cancer Immunol Res. 2015 Nov; 3(11):1201-6. [PubMed: 26216417]

62. Balch CM, Riley LB, Bae YJ, et al. Patterns of human tumor-infiltrating lymphocytes in 120 human cancers. Arch Surg. 1990 Feb; 125(2):200-5. [PubMed: 1689143]

63. Plautz GE, Barnett GH, Miller DW, et al. Systemic T cell adoptive immunotherapy of malignant gliomas. J Neurosurg. 1998 Jul; 89(1):42-51. [PubMed: 9647171]

64. Plautz GE, Miller DW, Barnett GH, et al. T cell adoptive immunotherapy of newly diagnosed gliomas. Clin Cancer Res. 2000 Jun; 6(6):2209-18. [PubMed: 10873070]

65. Morgan RA, Dudley ME, Wunderlich JR, et al. Cancer Regression in Patients After Transfer of Genetically Engineered Lymphocytes. Science. 2006; 314(5796):126-29. [PubMed: 16946036]

66. Stanislawski T, Voss RH, Lotz C, et al. Circumventing tolerance to a human MDM2-derived tumor antigen by TCR gene transfer. Nat Immunol. 2001 Oct; 2(10):962-70. [PubMed: 11577350]

67. Johnson LA, Morgan RA, Dudley ME, et al. Gene therapy with human and mouse T-cell receptors mediates cancer regression and targets normal tissues expressing cognate antigen. Blood. $2009 \mathrm{Jul}$ 16; 114(3):535-46. [PubMed: 19451549]

68. Xue SA, Gao L, Thomas S, et al. Development of a Wilms' tumor antigen-specific T-cell receptor for clinical trials: engineered patient's T cells can eliminate autologous leukemia blasts in NOD/ SCID mice. Haematologica. 2010 Jan; 95(1):126-34. [PubMed: 19679884]

69. Okamoto S, Mineno J, Ikeda H, et al. Improved expression and reactivity of transduced tumorspecific TCRs in human lymphocytes by specific silencing of endogenous TCR. Cancer Res. 2009 Dec 1; 69(23):9003-11. [PubMed: 19903853]

70. Govers C, Sebestyen Z, Coccoris M, et al. T cell receptor gene therapy: strategies for optimizing transgenic TCR pairing. Trends Mol Med. 2010 Feb; 16(2):77-87. [PubMed: 20122868]

71. Zhang L, Morgan RA. Genetic engineering with T cell receptors. Adv Drug Deliv Rev. 2012 Jun 1; 64(8):756-62. [PubMed: 22178904]

72. Parkhurst MR, Yang JC, Langan RC, et al. T cells targeting carcinoembryonic antigen can mediate regression of metastatic colorectal cancer but induce severe transient colitis. Mol Ther. $2011 \mathrm{Mar}$; 19(3):620-6. [PubMed: 21157437]

73**. Morgan RA, Chinnasamy N, Abate-Daga D, et al. Cancer regression and neurological toxicity following anti-MAGE-A3 TCR gene therapy. Journal of immunotherapy. 2013 Feb; 36(2):13351. A very important report demonstrating the importance of selecting appropriate antigens as well as previously unrecognized levels of susceptibility of the brain to T cell responses. [PubMed: 23377668]

Expert Opin Biol Ther. Author manuscript; available in PMC 2017 October 01. 
74. Morgan RA, Yang JC, Kitano M, et al. Case Report of a Serious Adverse Event Following the Administration of T Cells Transduced With a Chimeric Antigen Receptor Recognizing ERBB2. Mol Ther. 2010; 18(4):843-51. [PubMed: 20179677]

75. Robbins PF, Kassim SH, Tran TL, et al. A pilot trial using lymphocytes genetically engineered with an NY-ESO-1-reactive T-cell receptor: long-term follow-up and correlates with response. Clin Cancer Res. 2015 Mar 1; 21(5):1019-27. [PubMed: 25538264]

76. Rapoport AP, Stadtmauer EA, Binder-Scholl GK, et al. NY-ESO-1-specific TCR-engineered T cells mediate sustained antigen-specific antitumor effects in myeloma. Nat Med. 2015 Aug; 21(8): 914-21. [PubMed: 26193344]

77. Ngo MC, Rooney CM, Howard JM, et al. Ex vivo gene transfer for improved adoptive immunotherapy of cancer. Human Molecular Genetics. Apr 15; 2011 20(R1):R93-R99. [PubMed: 21415041]

78. Moeller M, Haynes NM, Trapani JA, et al. A functional role for CD28 costimulation in tumor recognition by single-chain receptor-modified T cells. Cancer Gene Ther. 2004; 11(5):371-79. [PubMed: 15060573]

79. Beckman RA, Weiner LM, Davis HM. Antibody constructs in cancer therapy - Protein engineering strategies to improve exposure in solid tumors. Cancer. 2007 Jan; 109(2):170-79. [PubMed: 17154393]

80. Weijtens M, Willemsen R, Valerio D, et al. Single chain Ig/gamma gene-redirected human T lymphocytes produce cytokines, specifically lyse tumor cells, and recycle lytic capacity. The Journal of Immunology. Jul 15; 1996 157(2):836-43. [PubMed: 8752936]

81. Maus MV, June CH. Making Better Chimeric Antigen Receptors for Adoptive T-cell Therapy. Clin Cancer Res. 2016 Apr 15; 22(8):1875-84. [PubMed: 27084741]

82. Kahlon KS, Brown C, Cooper LJ, et al. Specific recognition and killing of glioblastoma multiforme by interleukin 13-zetakine redirected cytolytic T cells. Cancer research. 2004 Dec 15; 64(24):9160-6. [PubMed: 15604287]

83. Ahmed N, Salsman VS, Kew Y, et al. HER2-specific T cells target primary glioblastoma stem cells and induce regression of autologous experimental tumors. Clin Cancer Res. 2010 Jan 15; 16(2): 474-85. [PubMed: 20068073]

84. Chow KK, Naik S, Kakarla S, et al. T cells redirected to EphA2 for the immunotherapy of glioblastoma. Mol Ther. 2013 Mar; 21(3):629-37. [PubMed: 23070117]

85. Ohno M, Ohkuri T, Kosaka A, et al. Expression of miR-17-92 enhances anti-tumor activity of Tcells transduced with the anti-EGFRvIII chimeric antigen receptor in mice bearing human GBM xenografts. Journal for immunotherapy of cancer. 2013; 1:21. [PubMed: 24829757]

86. Johnson LA, Scholler J, Ohkuri T, et al. Rational development and characterization of humanized anti-EGFR variant III chimeric antigen receptor T cells for glioblastoma. Sci Transl Med. 2015 Feb 18.7(275):275ra22.

87. Bullain SS, Sahin A, Szentirmai O, et al. Genetically engineered T cells to target EGFRvIII expressing glioblastoma. Journal of neuro-oncology. 2009 Sep; 94(3):373-82. [PubMed: 19387557]

88. Brown CE, Badie B, Barish ME, et al. Bioactivity and Safety of IL13Ralpha2-Redirected Chimeric Antigen Receptor CD8+ T Cells in Patients with Recurrent Glioblastoma. Clin Cancer Res. 2015 Sep 15; 21(18):4062-72. [PubMed: 26059190]

89. Pule MA, Savoldo B, Myers GD, et al. Virus-specific T cells engineered to coexpress tumorspecific receptors: persistence and antitumor activity in individuals with neuroblastoma. Nat Med. 2008 Nov; 14(11):1264-70. [PubMed: 18978797]

90. Hegde M, Corder A, Chow KK, et al. Combinational targeting offsets antigen escape and enhances effector functions of adoptively transferred T cells in glioblastoma. Mol Ther. 2013 Nov; 21(11): 2087-101. [PubMed: 23939024]

91. Kloss CC, Condomines M, Cartellieri M, et al. Combinatorial antigen recognition with balanced signaling promotes selective tumor eradication by engineered T cells. Nat Biotechnol. 2013 Jan; 31(1):71-5. [PubMed: 23242161]

Expert Opin Biol Ther. Author manuscript; available in PMC 2017 October 01. 
92. Wilkie S, van Schalkwyk MC, Hobbs S, et al. Dual targeting of ErbB2 and MUC1 in breast cancer using chimeric antigen receptors engineered to provide complementary signaling. J Clin Immunol. 2012 Oct; 32(5):1059-70. [PubMed: 22526592]

93. Grada Z, Hegde M, Byrd T, et al. TanCAR: A Novel Bispecific Chimeric Antigen Receptor for Cancer Immunotherapy. Mol Ther Nucleic Acids. 2013; 2:e105. [PubMed: 23839099]

94. Minagawa K, Zhou X, Mineishi S, et al. Seatbelts in CAR therapy: How Safe Are CARS? Pharmaceuticals (Basel). 2015; 8(2):230-49. [PubMed: 26110321]

95. Roybal KT, Rupp LJ, Morsut L, et al. Precision Tumor Recognition by T Cells With Combinatorial Antigen-Sensing Circuits. Cell. 2016 Feb 11; 164(4):770-9. [PubMed: 26830879]

96. Schumacher T, Bunse L, Pusch S, et al. A vaccine targeting mutant IDH1 induces antitumour immunity. Nature. 2014 06/25/online; advance online publication.

97. Cameron BJ, Gerry AB, Dukes J, et al. Identification of a Titin-derived HLA-A1-presented peptide as a cross-reactive target for engineered MAGE A3-directed T cells. Sci Transl Med. 2013 Aug 7.5(197):197ra03.

98. Sampson JH, Heimberger AB, Archer GE, et al. Immunologic Escape After Prolonged Progression-Free Survival With Epidermal Growth Factor Receptor Variant III Peptide Vaccination in Patients With Newly Diagnosed Glioblastoma. Journal of Clinical Oncology. Nov 1; 2010 28(31):4722-29. [PubMed: 20921459]

99. Kohanbash G, Okada H. Myeloid-derived suppressor cells in gliomas and glioma-development. Immunol Invest. 2012; 41(6-7):658-79. [PubMed: 23017140]

100. Okada H, Butterfield LH, Hamilton RL, et al. Induction of Robust Type-I CD8+ T-cell Responses in WHO Grade 2 Low-Grade Glioma Patients Receiving Peptide-Based Vaccines in Combination with Poly-ICLC. Clinical cancer research : an official journal of the American Association for Cancer Research. 2015 Jan 15; 21(2):286-94. [PubMed: 25424847]

101. Okada H, Tsugawa T, Sato H, et al. Delivery of Interferon-alpha transfected dendritic cells into central nervous system tumors enhances the antitumor efficacy of peripheral peptide-based vaccines. Cancer Res. 2004; 64(16):5830-38. [PubMed: 15313927]

102. Pollack IF, Jakacki RI, Butterfield LH, et al. Antigen-specific immune responses and clinical outcome after vaccination with glioma-associated antigen peptides and polyinosinicpolycytidylic acid stabilized by lysine and carboxymethylcellulose in children with newly diagnosed malignant brainstem and nonbrainstem gliomas. J Clin Oncol. 2014 Jul 1; 32(19): 2050-8. [PubMed: 24888813]

103. Kershaw MH, Wang G, Westwood JA, et al. Redirecting migration of T cells to chemokine secreted from tumors by genetic modification with CXCR2. Human gene therapy. 2002 Nov 1; 13(16):1971-80. [PubMed: 12427307]

104. Di Stasi A, De Angelis B, Rooney CM, et al. T lymphocytes coexpressing CCR4 and a chimeric antigen receptor targeting CD30 have improved homing and antitumor activity in a Hodgkin tumor model. Blood. 2009 Jun 18; 113(25):6392-402. [PubMed: 19377047]

105. Craddock JA, Lu A, Bear A, et al. Enhanced tumor trafficking of GD2 chimeric antigen receptor T cells by expression of the chemokine receptor CCR2b. J Immunother. 2010 Oct; 33(8):780-8. [PubMed: 20842059]

106. Moon EK, Carpenito C, Sun J, et al. Expression of a functional CCR2 receptor enhances tumor localization and tumor eradication by retargeted human $\mathrm{T}$ cells expressing a mesothelin-specific chimeric antibody receptor. Clin Cancer Res. 2011 Jul 15; 17(14):4719-30. [PubMed: 21610146]

107. Grossman SA, Ye X, Lesser G, et al. Immunosuppression in Patients with High-Grade Gliomas Treated with Radiation and Temozolomide. Clinical Cancer Research. Aug 15; 2011 17(16): 5473-80. [PubMed: 21737504]

108. Chmielewski M, Abken H. TRUCKs: the fourth generation of CARs. Expert opinion on biological therapy. 2015; 15(8):1145-54. [PubMed: 25985798]

109. Kerkar SP, Muranski P, Kaiser A, et al. Tumor-specific CD8+ T cells expressing interleukin-12 eradicate established cancers in lymphodepleted hosts. Cancer research. 2010 Sep 1; 70(17): 6725-34. [PubMed: 20647327]

Expert Opin Biol Ther. Author manuscript; available in PMC 2017 October 01. 
110. Zhang L, Kerkar SP, Yu Z, et al. Improving adoptive T cell therapy by targeting and controlling IL-12 expression to the tumor environment. Mol Ther. 2011 Apr; 19(4):751-9. [PubMed: 21285960]

111. Chmielewski M, Kopecky C, Hombach AA, et al. IL-12 release by engineered T cells expressing chimeric antigen receptors can effectively Muster an antigen-independent macrophage response on tumor cells that have shut down tumor antigen expression. Cancer research. 2011 Sep 1; 71(17):5697-706. [PubMed: 21742772]

112. Bollard CM, Rossig C, Calonge MJ, et al. Adapting a transforming growth factor beta-related tumor protection strategy to enhance antitumor immunity. Blood. 2002 May 1; 99(9):3179-87. [PubMed: 11964281]

113. Abate-Daga D, Hanada K, Davis JL, et al. Expression profiling of TCR-engineered T cells demonstrates overexpression of multiple inhibitory receptors in persisting lymphocytes. Blood. 2013 Aug 22; 122(8):1399-410. [PubMed: 23861247]

114. John LB, Devaud C, Duong CP, et al. Anti-PD-1 antibody therapy potently enhances the eradication of established tumors by gene-modified T cells. Clin Cancer Res. 2013 Oct 15; 19(20):5636-46. [PubMed: 23873688]

115. John LB, Kershaw MH, Darcy PK. Blockade of PD-1 immunosuppression boosts CAR T-cell therapy. Oncoimmunology. 2013 Oct 1.2(10):e26286. [PubMed: 24353912]

116. Okada H, Pollack IF. Do we need novel radiologic response criteria for brain tumor immunotherapy? Expert Review of Neurotherapeutics. 2011 May 01; 11(5):619-22. [PubMed: 21539483]

117*. Okada H, Weller M, Huang R, et al. Immunotherapy Response Assessment in Neuro-Oncology (iRANO): A Report of the RANO Working Group. Lancet Oncol. 2015; 15:534-42. This proposes a novel response criteria specifically designed for immunotherapy of brain tumors.

118. Wolchok JD, Hoos A, O’Day S, et al. Guidelines for the Evaluation of Immune Therapy Activity in Solid Tumors: Immune-Related Response Criteria. Clinical Cancer Research. Dec 1; 2009 15(23):7412-20. [PubMed: 19934295]

119. Wen PY, Macdonald DR, Reardon DA, et al. Updated Response Assessment Criteria for HighGrade Gliomas: Response Assessment in Neuro-Oncology Working Group. Journal of Clinical Oncology. Apr 10; 2010 28(11):1963-72. [PubMed: 20231676]

Expert Opin Biol Ther. Author manuscript; available in PMC 2017 October 01. 


\section{Article Highlights Box}

- Cellular immunotherapeutics could be classified into vaccine approaches and adoptive transfer of effector cell approaches.

- Cellular vaccine approaches utilize tumor cells and/or antigen presenting cells, such as dendritic cells.

- $\quad$ Adoptive cell transfer (ACT) approaches can utilize a variety of effector cell types, including lymphokine-activated killer (LAK) cells, $\gamma \delta \mathrm{T}$ cells, tumor-infiltrating lymphocytes (TIL), chimeric antigen receptor (CAR)-T cells and T-cell receptor (TCR) transduced T cells.

- $\quad$ The ultimate success of cellular immunotherapy in brain tumor patients would require improvements in the areas including feasibility in producing cellular therapeutics as well as strategies to promote effector T-cell trafficking to the tumor site and to overcome local and systemic immune suppression.

With advances of technologies allowing antigen-specific targeting of ACTs, it is critical to expand the list of glioma-speicific antigens that can be safely targeted in future immunotherapies. 


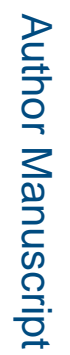

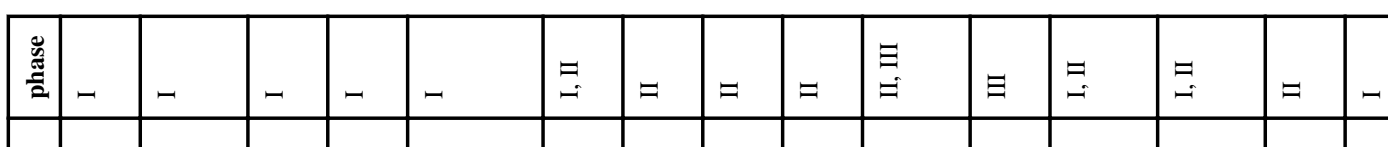

\}

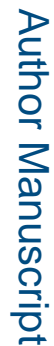

ᄅ

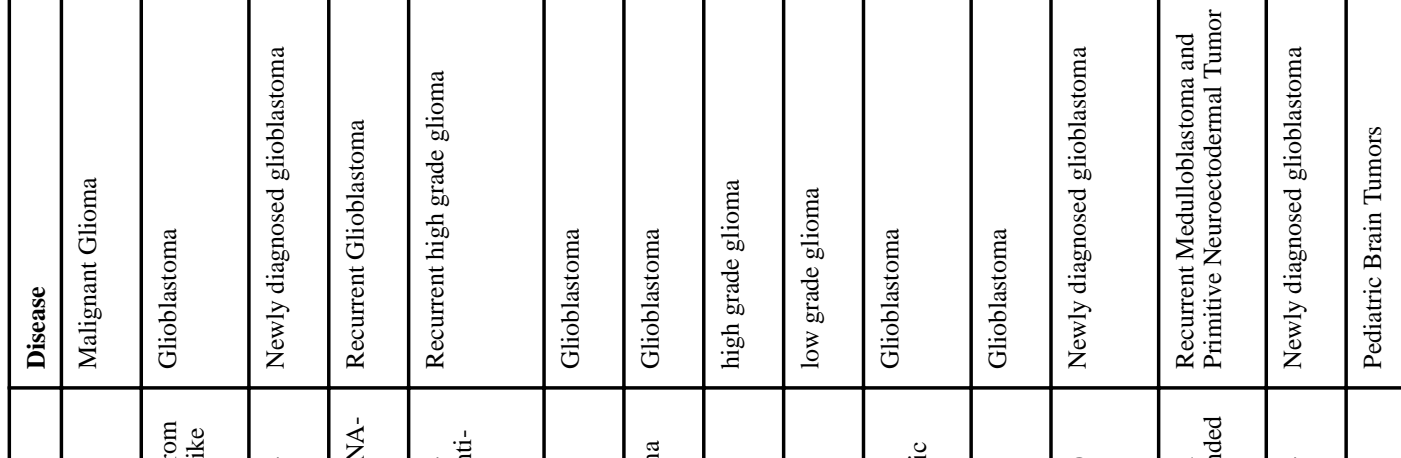

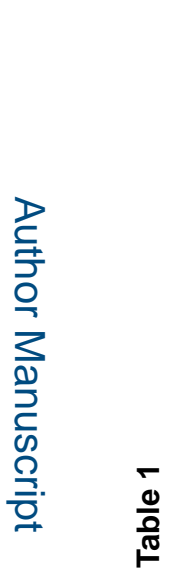

离

光

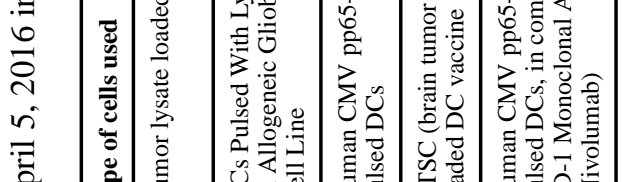

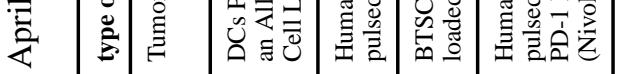

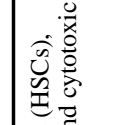

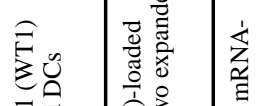

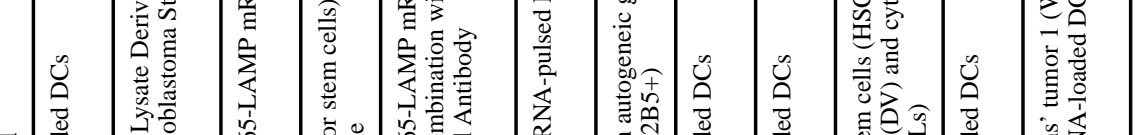

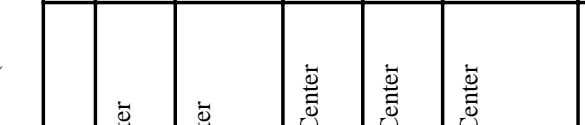

莺

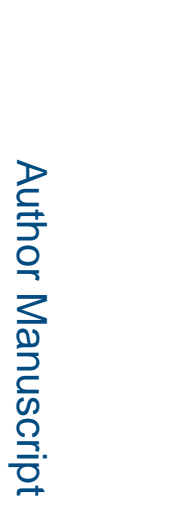

寻

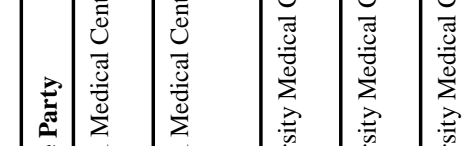

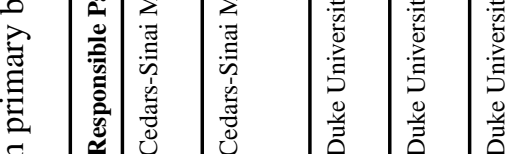

考

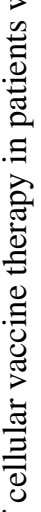

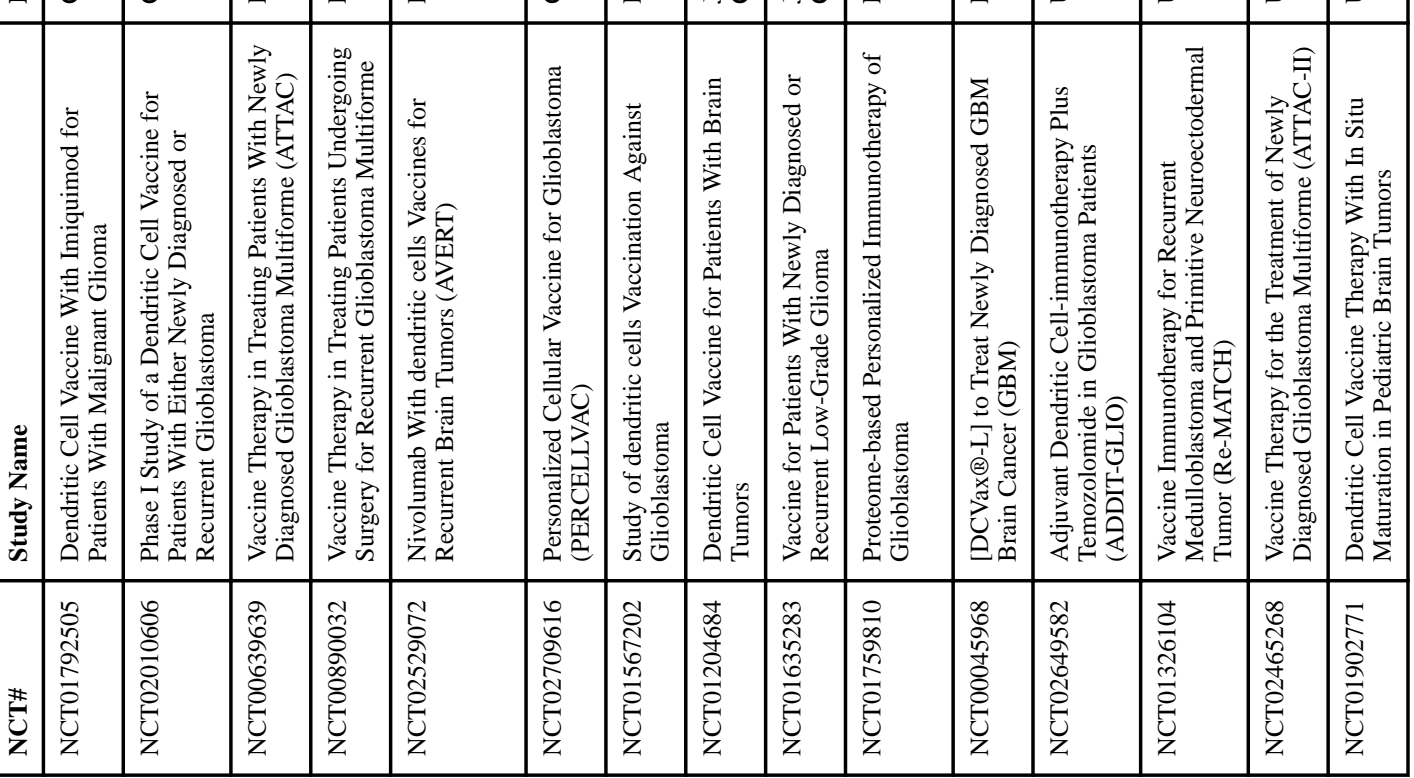

Expert Opin Biol Ther. Author manuscript; available in PMC 2017 October 01. 


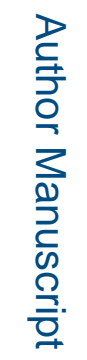

\begin{tabular}{|c|c|c|c|c|c|c|c|c|c|c|c|}
\hline 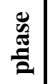 & $=$ & $\begin{array}{l}\exists \\
= \\
=\end{array}$ & $\exists$ & $\exists$ & - & - & - & - & - & $\Rightarrow$ & $\Rightarrow$ \\
\hline
\end{tabular}
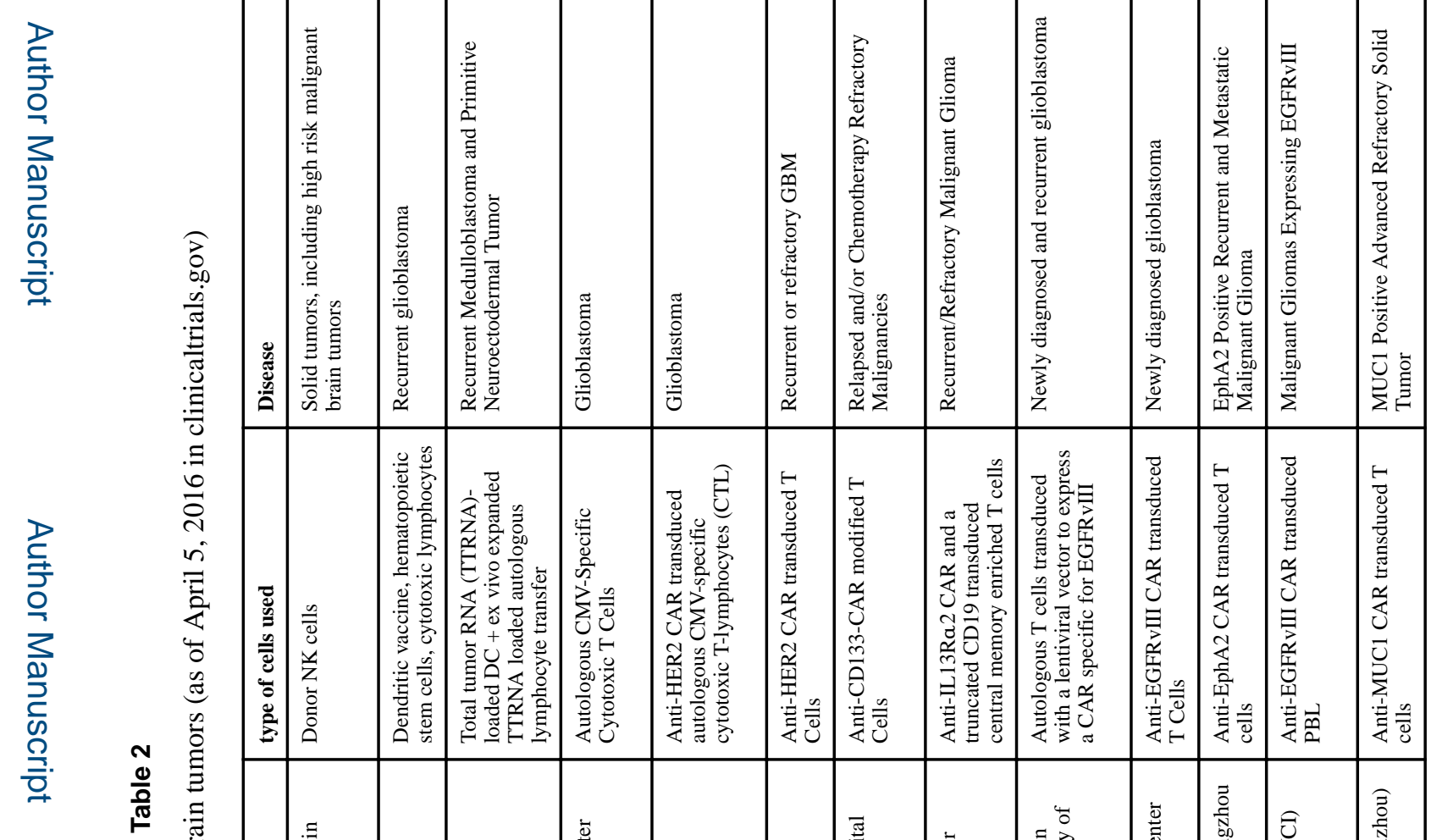

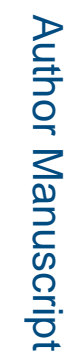

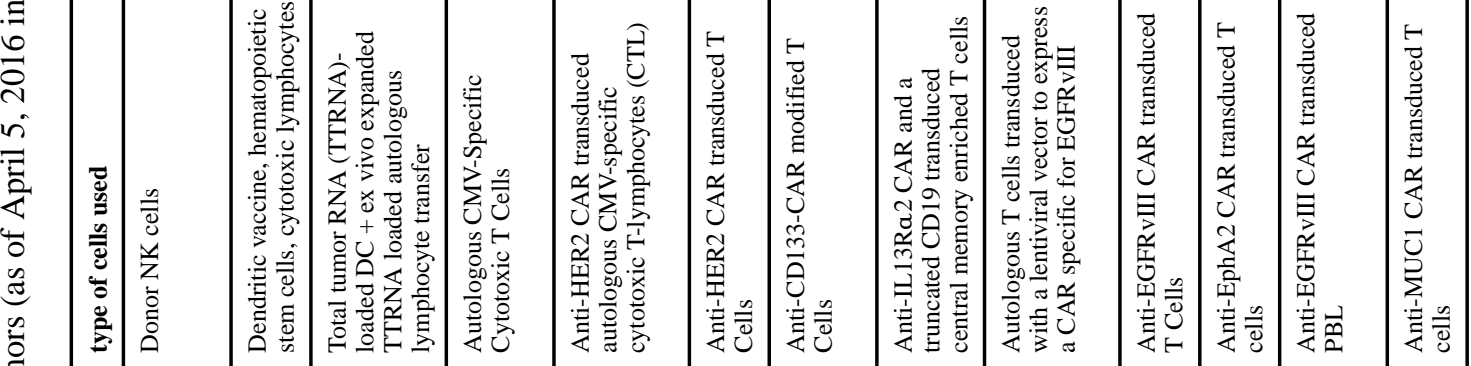

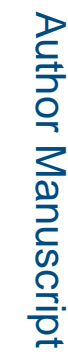

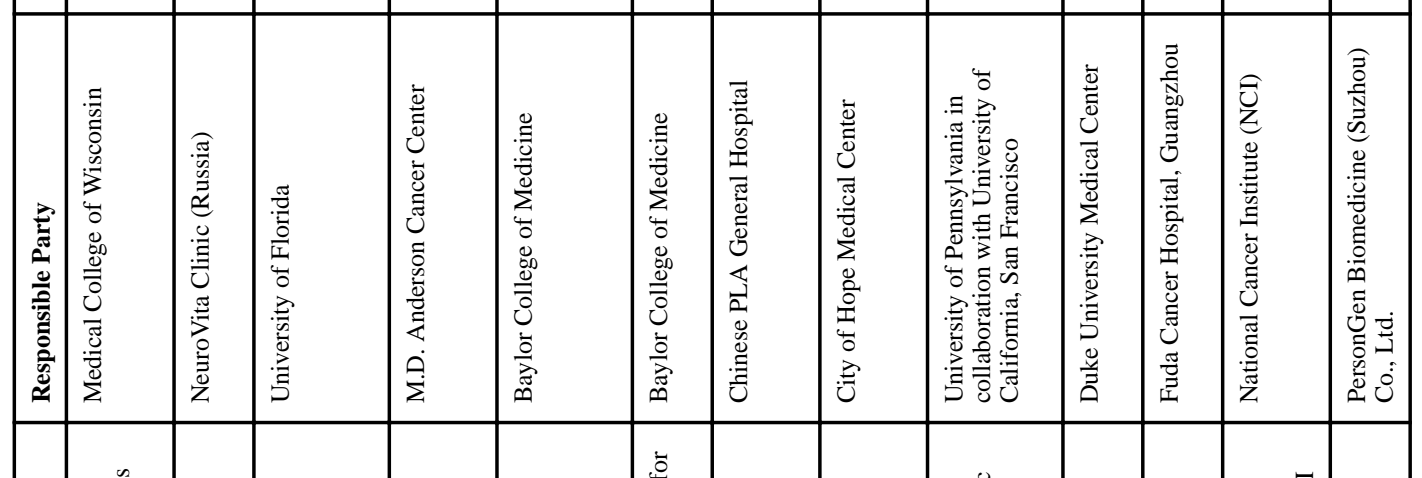

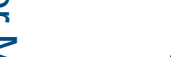

\begin{tabular}{|c|c|c|c|c|c|c|c|c|c|c|c|c|c|}
\hline 气ू̆ & 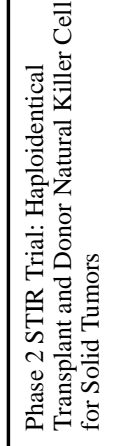 & 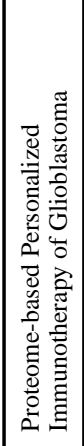 & 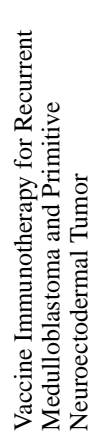 & 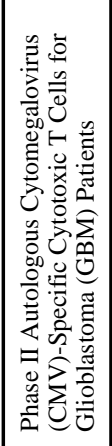 & 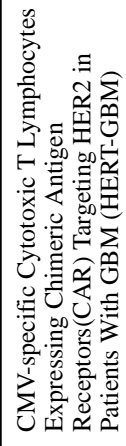 & 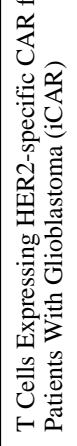 & 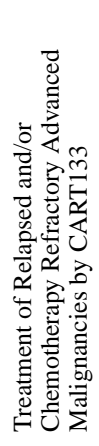 & 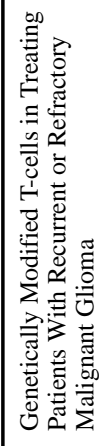 & 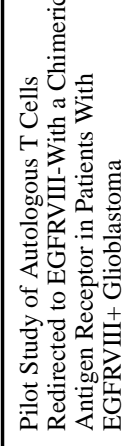 & 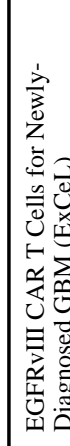 & 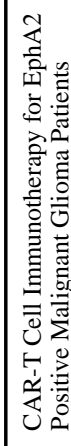 & 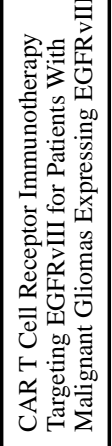 & 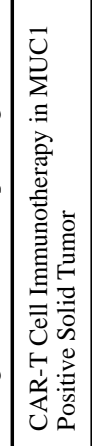 \\
\hline & 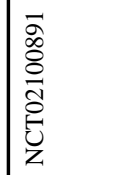 & 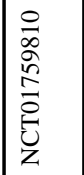 & 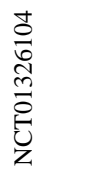 & 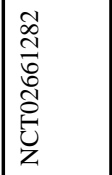 & 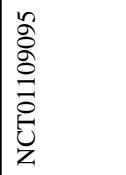 & 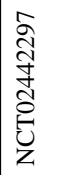 & 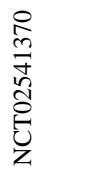 & 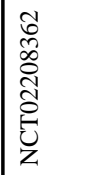 & 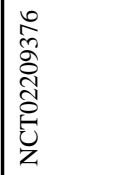 & 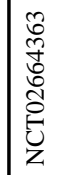 & 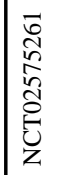 & 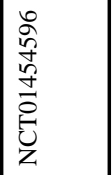 & \\
\hline
\end{tabular}

Expert Opin Biol Ther. Author manuscript; available in PMC 2017 October 01. 


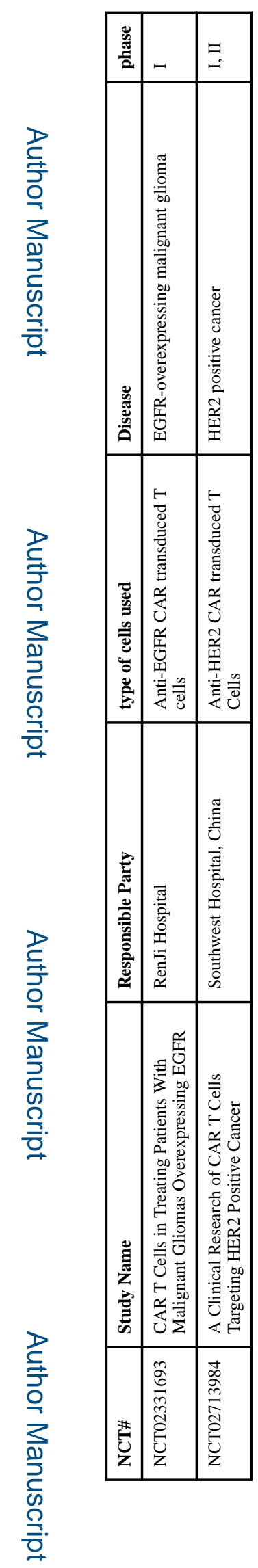

Expert Opin Biol Ther. Author manuscript; available in PMC 2017 October 01. 